\title{
The Relationship between Experiential Marketing and Corporate Reputation: A Research on Turkish Operator Companies
}

\author{
Ph.D. Osman Özdemir \\ Şırnak University, Faculty of Economics and Administrative Sciences, Şırnak \\ Prof. Şakir Erdem \\ Marmara University, Faculty of Business Administration, Istanbul
}

\begin{abstract}
The main purpose of this study is to investigate whether the experiential marketing components are related to corporate reputation. It focuses on the relationship of sensory, emotional, cognitive, behavioral and relational experiences to corporate reputation components. In addition, the mediator effects of environment and social media on this relationship has been examined.In the qualitative research part of the research, a large study was done in the literature. Afterwards, negotiations were held with academicians and managers who are experts in the field. It was pretested with validity and reliability and accepted scales. After making the necessary changes, the survey collection phase was passed. In the quantitative research part of the study, face-to-face interviews and survey data filled by 464 people were used. The relationship between experiential marketing and corporate reputation has been tested by structural equation modeling. According to this, path analysis between experiential marketing and corporate reputation was established and relations were found meaningful and positively. While there is a significant effect of the environmental variable, the effect of the social media variable was not found.
\end{abstract}

Keywords: Experiential Marketing, Corporate Reputation

\section{Introduction}

Reputation provides for businesses positive perception by economic, political and social environment allowing the business to grow both locally and globally. Today, developed markets are reaching saturation and emerging markets gain importance. In emerging markets, businesses will have the experience and reputation that will enable them to take place with low risk and high control. (Dima vd., 2013: 52-53).

The desired outcome for businesses is to have a strong corporate reputation. In this context, businesses need to focus on emotional appeal, quality goods and services, vision and leadership, reliable business environment, financial performance indicators and social responsibility activities. (Fombrun ve Shanley, 1990, 233).

\section{Theoretical Background of Experiential Marketing and Corporate ReputationThe desired}

\subsection{Experiential Marketing}

In experiential marketing there are goods, services and experiences aimed at providing sensory, emotional, cognitive, physical and social experiences to consumers. Today, it is stated that customer experience management concept is needed instead of customer relationship management concept in marketing activities. Emphasis is placed on the importance of employees' experiences and the need to give importance to employee experiences for their reputation (Torlak, 2007: 50).

Sensory experience is perceived experiences with five sensory organs. It implies that experience is perceived as different and beneficial. It is evaluated in this context that businesses experience contact with consumers at the contact points. For example, P\&G brand of detergents are keeping on odor, whiteness and softness reveals the importance of senses in consumer preference (Deligöz, 2016: 35-37).

Consumers have psychological and sociological characteristics, and their behavior is also based on emotional reasons. The research on corporate reputation emphasizes the importance of the emotional experience of businesses. It is desirable 
that businesses are reliable, honest, ethical, helpful, hospitable and responsive (Zaltman, 2004: 203-204)

Businesses need to understand and meet the needs, desires and fears of consumers. Therefore, corporate reputation can be increased by interaction and empathy. Employees with an empathic sense make customers feel better and increase their commitment to business (Freemantle, 2000: 143-144).

The preference of the businesses depends on being an advanced technology, reliable, innovative, creative and proactive. The fact that businesses differ from their competitors because oftheir presenting experiences. Experiences affect the rational decisions of consumers (Zaltman, 2004: 188-189).

Businesses want consumer to change life positively with experiential marketing. For example, Starbucks positions itself as an alternative to home, office or library. Since consumer are motivated not just for coffee, but sitting for hours to chat, meet or study (Kalyoncuoğlu, 2017: 69).

Relational experience is an experience that includes other experiential marketing components. In this experience, which focuses on the social relations of consumers with their business and other customers. Since customers are associated with goods, services and experiences. For example, consumers who adopt the Harley-Davidson brand, see themselves as members of a group and live their sense of belonging with a lifestyle (Schmitt, 1999: 173). On the other hand, businesses increase their earnings through the size of the community whilecustomers can consume together with the community (Yaman - Zerenler, 2018: 78).

\subsection{Corporate Reputation}

Admiration, esteem and trust towards businesses are features that enhance emotional appeal. Another feature that enhances emotional appeal is that businesses are included in donation campaigns. These increase profitability, market share and corporate reputation (Fombrun - Shanley, 1990: 251).

High quality goods and services provide for businesses significant advantages. It increases not only corporate reputation but also a long-term advantage with repayments maintance and profitability is long-lived. The sharing of goods and service provision with word of mouth will cause those who want to experience them. In particular, social media are influencing and directing consumers in search of experience (Caruana, 1997: 110).

The people who set the vision in the business are seen as the leaders. It is stated as a successful talent that the leaders have the ability to act, maintain and give experience to his employees. In addition, employees who believe in their leader can relate between today and the future. Leaders with a high level of communication skills are also involved in understanding the vision, relating it to values and achieving it. (Morden, 1997: 668).

In today's management concept, the business environment has changed in recent years. The adoption of an open system in the business environment is aimed at increasing the relations among employees and creating synergy. Leaders want to increase the motivation of employees. Therefore the business environment is shaped. The vision of the business is also seen as a motivating tool and is used to achieve long-term goals (Bareket, 2012: 433-434).

Consumers behave cognitively and emotionally when evaluating businesses' past and present financial strengths. Strong businesses that have financial power indicates have strong reputation. In corporate reputation scales, the evaluations are based on the financial indicators of the previous years. The evaluation of financial performance is about comparing with businesses and competitors's past and present situation. Sustainable competitive advantage can be seen in this context. (Inglis, 2006: 936).

Businesses' social responsibility activities in global markets are handled with a balanced approach to the values of different cultures. Experiences are presented should take into account the aims of the business, the needs of the community and cultural pressures. The return of these experiences to business is an increase in economic performance and a positive corporate reputation. In this context, social responsibility activities are not considered as a cost but as a strategic investment (Dima et al., 2013: 53-54).

\subsection{The Environment and Social Media}

The environment and social media affect business relations. Corporate reputation of businesses in the globalizing world depend on their environment and social media activities. The environment have features economic, politic, technological, 
culturel and competitional. On the other hand, consumers' knowledge and motivation of social media to use social media are also affecting businesses today.

\section{Conceptual Framework and Hypotheses}

Based on the previous research the following hypotheses have been listed to be tested.

$\mathrm{H1}$ : Experiential marketing is significantly related to corporate reputation.

H1a: Sensory experience is significantly related to corporate reputation.

$\mathrm{H} 1 \mathrm{~b}$ : Emotional experience is significantly related to corporate reputation.

H1c: Cognitive experience is significantly related to corporate reputation.

H1d: Behavioral experience is significantly related to corporate reputation.

H1e: Relational experience is significantly related to corporate reputation.

$\mathrm{H} 2$ : Environment affects the relationship between experiential marketing and corporate reputation.

$\mathrm{H} 3$ : Social media affects the relationship between experiential marketing and corporate reputation.

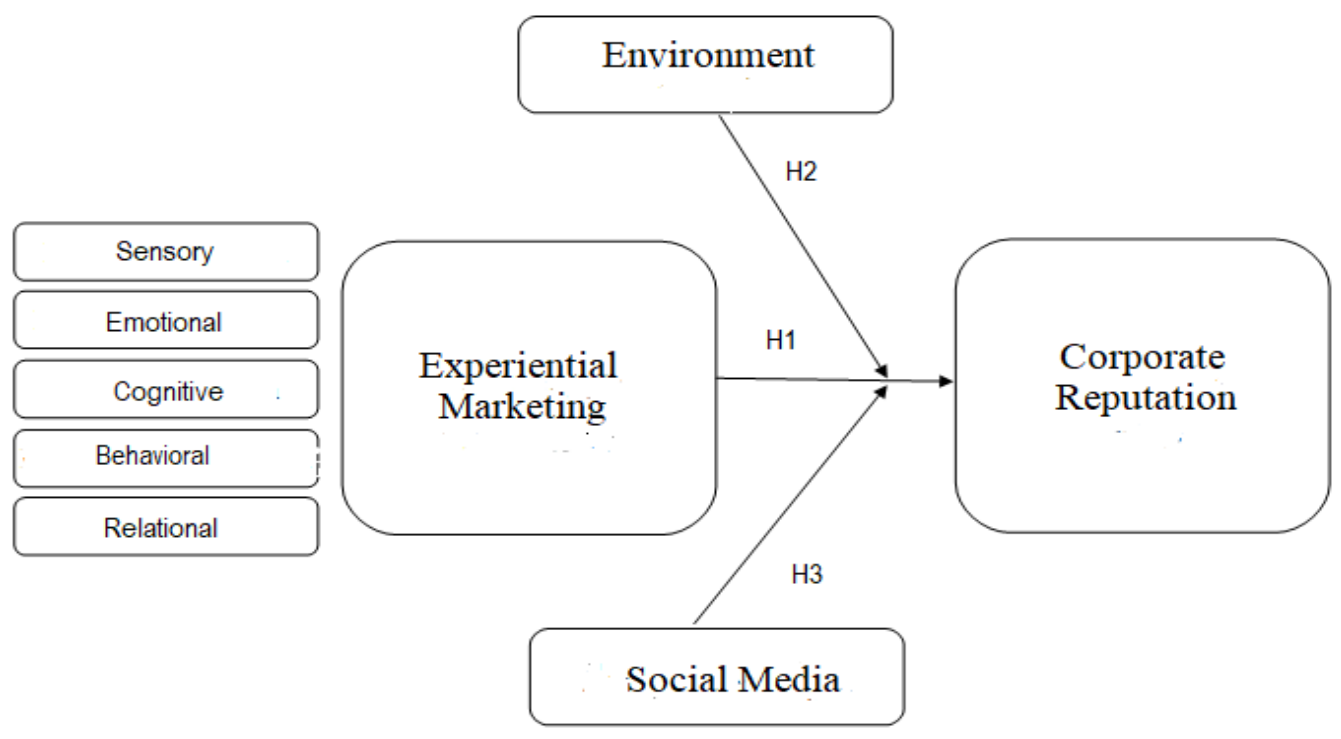

Figure 1. Conceptual Model

Based on these hypotheses, the research model is structured to explain how sensory, emotional, cognitive, behavioral, relational experience affect corporate reputation through environment.

\section{Methodology}

\section{a. Measures}

A review of the literature yielded a number of measurement instruments that were employed to test the hypothesized model and each scale has a history of reliable measurement (See Table 2). All scales employed in this study were measured on five-point Likert scales ranging from 1 (strongly disagree) to 5 (strongly agree). In the process of translation, the techniques of back translation and parallel translation have been adopted with the help of a group of academicians fluent in English and Turkish. The final Turkish version of the questionnaire was further verified by the authors of this paper. 
Table 1. Measurement items

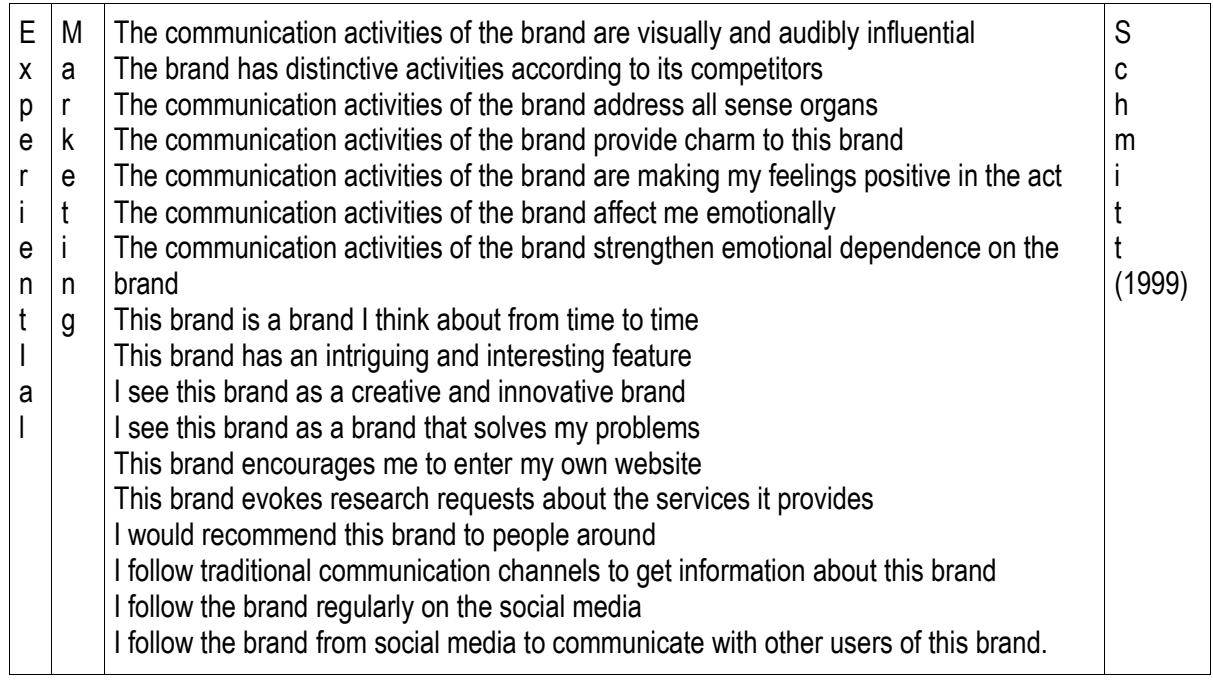

\begin{tabular}{|l|l|l|}
\hline C & I have positive feelings about this brand & $\mathrm{F}$ \\
$\mathrm{o}$ & I trust this brand & $\mathrm{0}$ \\
$\mathrm{r}$ & This brand is a respected brand & $\mathrm{m}$ \\
$\mathrm{p}$ & I am proud to use this brand & $\mathrm{b}$ \\
$\mathrm{o}$ & This brand stands behind the services it offers & $\mathrm{r}$ \\
$\mathrm{r}$ & This brand offers innovative services & $\mathrm{u}$ \\
$\mathrm{a}$ & This brand offers high quality services & $\mathrm{n}$ \\
$\mathrm{t}$ & This brand offers valuable services for the fee I pay & etc. \\
$\mathrm{e}$ & This brand has a clear and understandable future vision \\
$\mathrm{R}$ & This brand has a strong leader and valuable executives within the organization & $(2000)$ \\
$\mathrm{e}$ & This brand has the ability to see market opportunities & \\
$\mathrm{p}$ & This brand is managed well and correctly & \\
$\mathrm{u}$ & I think this brand has good and qualified employees & \\
$\mathrm{t}$ & I think this brand has the ambience to create a work request & \\
$\mathrm{a}$ & I think this brand has a very strong profitability history & \\
$\mathrm{t}$ & I think this mark does not invest in risky areas & \\
$\mathrm{I}$ & I think this brand has the potential for further growth in the future & \\
$\mathrm{o}$ & I think this brand has better economic performance than its competitors & \\
$\mathrm{n}$ & This brand offers people a high standard of quality & \\
& This brand is environmentally responsible & \\
& This brand supports charitable activities with social responsibility activities & \\
\hline
\end{tabular}




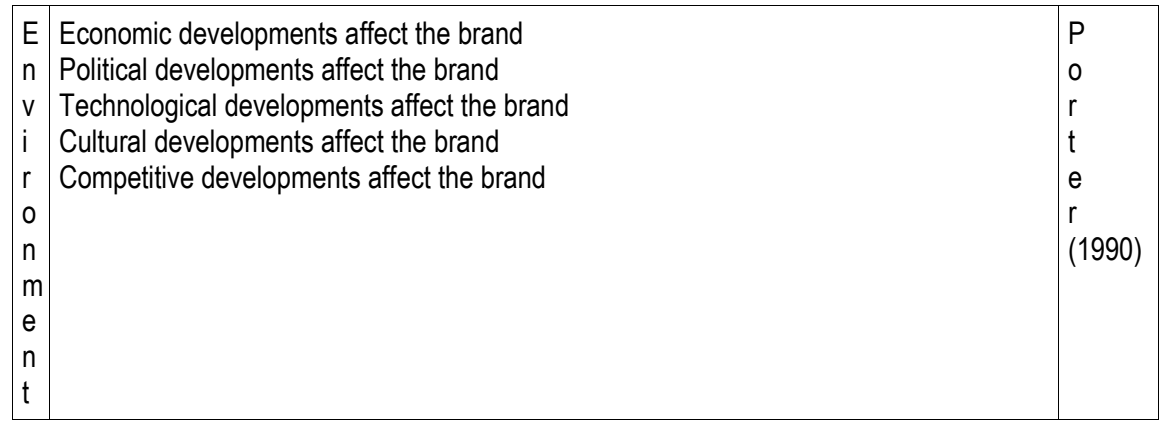

\begin{tabular}{|c|c|c|}
\hline 0 & $\begin{array}{l}\text { I like to enter social media for information } \\
\text { Social media is available for information } \\
\text { Learning marketing communication activities of the brand from social media } \\
\text { I keep track of developments, innovations and existing product updates on brands } \\
\text { from social media } \\
\text { I like to get social media information about brands and exchange ideas about them } \\
\text { The feeling of self-motivation motivates me to participate and use in social media } \\
\text { communities (Facebook etc.) } \\
\text { To motivate me to participate and use social media communities to realize personal } \\
\text { goals (to get information about products and brands etc.) } \\
\text { Supporting other social media users in the direction of my knowledge motivates me } \\
\text { to participate and use social media communities }\end{array}$ & $\begin{array}{l}\text { C } \\
h \\
a \\
h \\
a \\
\text { l } \\
\text { and } \\
\text { R } \\
\text { a } \\
\text { n } \\
\text { i } \\
(2017\end{array}$ \\
\hline
\end{tabular}

\section{b. Sampling and Data Collection}

Data for this research was collected through a questionnaire survey. During four week period, more than 480 respondents completed the survey. After sorting and removing duplicate submissions, a net sample of 464 usable questionnaires remained. The major demographics of the respondents were listed in Table 2.

Table 2. Demographic characteristics of survey respondents $(\mathrm{N}=464)$

\begin{tabular}{|c|c|c|c|c|c|c|c|c|}
\hline Gender & \multicolumn{4}{|c|}{$\begin{array}{c}\text { Female } \\
\% 54,1\end{array}$} & \multicolumn{4}{|c|}{$\begin{array}{l}\text { Male } \\
\% 45,9\end{array}$} \\
\hline Age & $\begin{array}{l}\mathbf{1 8 - 2 4} \\
\% 16,6\end{array}$ & \multicolumn{3}{|c|}{$\begin{array}{l}\mathbf{2 5 - 3 4} \\
\% 51,7\end{array}$} & $\begin{array}{l}\mathbf{3 5 - 4 4} \\
\% 19,4\end{array}$ & \multicolumn{2}{|c|}{$\begin{array}{l}\mathbf{4 5 - 5 4} \\
\% 9,5\end{array}$} & $\begin{array}{l}\mathbf{5 5 - 6 4} \\
\% 2,8\end{array}$ \\
\hline $\begin{array}{l}\text { Marital } \\
\text { Status }\end{array}$ & \multicolumn{4}{|c|}{$\begin{array}{l}\text { Single } \\
\% 56,3\end{array}$} & \multicolumn{4}{|c|}{$\begin{array}{c}\text { Married } \\
\% 43,8\end{array}$} \\
\hline Education & $\begin{array}{c}\text { Secondary } \\
\% 1,3\end{array}$ & $\begin{array}{c}\text { High } \\
\text { School } \\
\% 6\end{array}$ & \multicolumn{2}{|c|}{$\begin{array}{c}2 \text { year Degree } \\
\% 13,6\end{array}$} & $\underset{\% 33}{\text { University }}$ & \multicolumn{2}{|c|}{$\underset{\% 36,2}{\text { Graduate }}$} & $\begin{array}{l}\text { PhD } \\
\% 9,9\end{array}$ \\
\hline Occupation & \multicolumn{4}{|c|}{$\begin{array}{c}\text { Public sector } \\
\% 45,9\end{array}$} & \multicolumn{4}{|c|}{$\begin{array}{c}\text { Private sector } \\
\% 54,1\end{array}$} \\
\hline Income & $\begin{array}{l}\text { Under than } \\
\text { 1000TL } \\
\% 3,4\end{array}$ & $\begin{array}{l}\text { 1001- } \\
\text { 2000TL } \\
\text { arası } \\
\% 12,1\end{array}$ & \begin{tabular}{|l|} 
2001- \\
3000TL \\
arası \\
$\% 24,6$
\end{tabular} & $\begin{array}{l}\text { 3001- } \\
\text { 4000TL } \\
\text { arası } \\
\% 26,3\end{array}$ & $\begin{array}{l}\text { 4001- } \\
\mathbf{5 0 0 0 T L} \\
\text { aras1 } \\
\% 18,5\end{array}$ & \begin{tabular}{|l|}
$\mathbf{5 0 0 1 -}$ \\
$\mathbf{7 5 0 0 T L}$ \\
arası \\
$\% 9,7$
\end{tabular} & $\begin{array}{l}7501- \\
\text { 10BinTL } \\
\text { aras1 } \\
\% 2,8\end{array}$ & $\begin{array}{l}\text { More than } \\
\text { 10BinTL } \\
\% 2,6\end{array}$ \\
\hline
\end{tabular}


The sample comprised of 251 Female and 213 Male. Ages of the sample ranged between 18 to 60 . Data obtained from questionnaires will be analyzed through the IBM SPSS 23.0 and AMOS 22.0 statistical programs

\section{Analysis and Findings}

The main purpose of the study is structured to explain how sensory, emotional, cognitive, behavioral, relational experience affect corporate reputation through environment. To identify and test the underlying structure of the scales exploratory factor analyses (EFA) were employed to each measurement as the initial step. The EFA results were further validated with confirmatory factor analyses (CFA). Kaiser-Meyer-Olkin measure of sampling adequacy and Bartlett test of sphericity tests were performed to test the appropriateness of data for conducting factor analyses (Sharma, 1996)

The KMO test results are above the accepted limit of 0.50 for each factor. In the Bartlett test results, it is seen that $p$ value is significant and below 0,05 . In this context, it is appropriate to perform factor analysis with the existing data set.

Each factor has a Cronbach Alpha value greater than 0.70 , which is the result of the reliability analysis.

\begin{tabular}{|l|l|l|c|l|c|}
\hline Experiential Marketing & CMIN & DF & CMIN/DF & CFI & RMSEA \\
\hline & 416,287 & 108 & 3,855 &, 929 &, 079 \\
\hline Corporate Reputation & CMIN & DF & CMIN/DF & CFI & RMSEA \\
\hline & 568,036 & 174 & 3,265 &, 944 &, 070 \\
\hline Environment & CMIN & DF & CMIN/DF & CFI & RMSEA \\
\hline & 12,578 & 4 & 3,145 &, 992 &, 068 \\
\hline Social Media & CMIN & DF & CMIN/DF & CFI & RMSEA \\
\hline & 25,634 & 7 & 3,662 &, 988 &, 076 \\
\hline
\end{tabular}

Table 3. Results of CMIN/DF, CFI and RMSEA

The results of confirmatory factor analysis seem to be consistent with the theoretical basis. CMIN / DF values are below 5.00. It is stated that values below 5.00 are acceptable (Marsh and Hocevar, 1985). CFI values are close to 1.00. This

\begin{tabular}{|l|l|l|l|l|c|l|c|}
\hline $\begin{array}{l}\text { Path } \\
\text { Analysis }\end{array}$ & CMIN & DF & CMIN/DF & CFI & GFI & AGFI & RMSEA \\
\hline & 5,894 & 4 & 1,473 &, 998 &, 995 &, 981 &, 032 \\
\hline
\end{tabular}

indicates that the compliance indices are very good and meaningful (Bentler, 1990). The RMSEA values are below 0.08 and represent a very good fit. (Browne - Cudeck, 1993)

\section{Table 4. Result of Path Analysis}

As a result of the path analysis, it is understood that the fit and the predictive power are statistically significant. The CMIN I DF value has risen to 1.473 below the 5.00 value and is stated in the literature that values below 5.00 are acceptable (Marsh and Hocevar, 1985).

The CFI value is 0.988 and is close to 1.00 . In this context, it can be said that it has a very good harmony value. NFI, RFI, IFI and TLI values are consistent with the values of 0,993, 0,982, 0,998 and 0,994 (Bentler, 1990).

The GFI value expresses the goodness of fit index and it is 0,995 and it shows perfect fit with the value close to 1.00 (Tanaka - Huba, 1985). The AGFI value is 0.981 and the value close to 1.00 with a good fit. 
The RMSEA value is 0.032 , which is lower than 0.08 , indicating the perfect level of conformity in the model (Browne Cudeck, 1993).

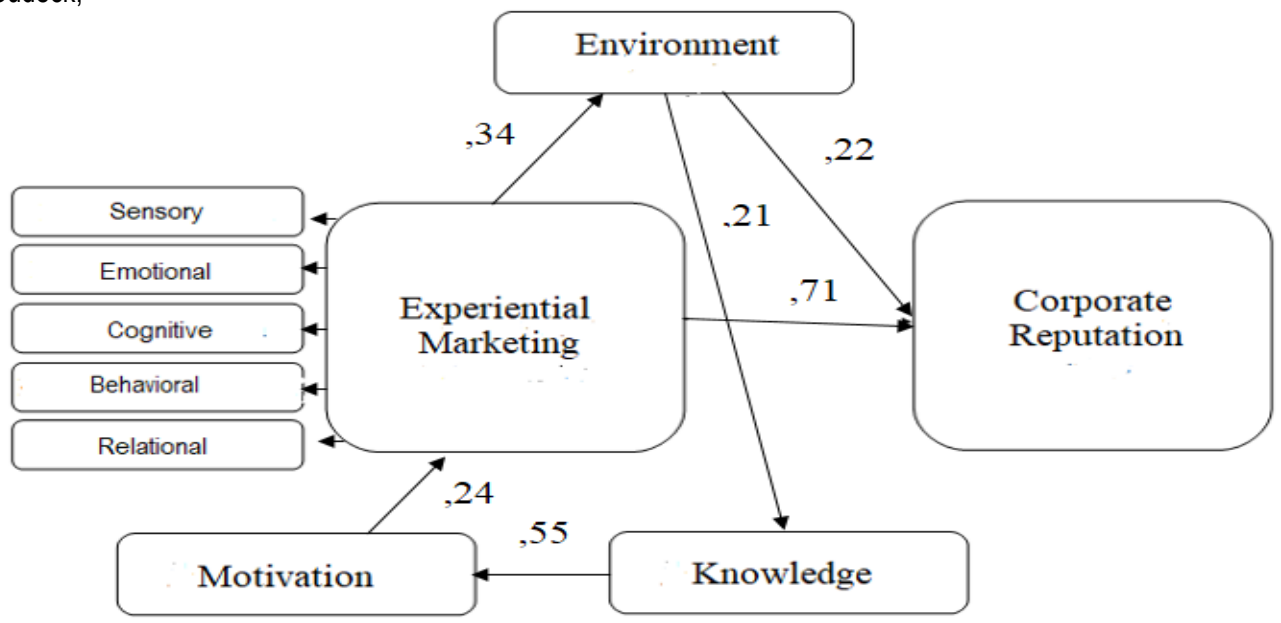

Figure 2. Graphical representation of path model

When the results for the standard direct effect in path analysis are examined, there is a 0.71 relationship between experiential marketing and corporate reputation; there is a 0.55 relationship between social media knowledge and social media motivation; there is a 0.34 relationship between experiential marketing and the environment. In this context, it can be said that the variables have significant relations with each other in the positive direction.

When the standard indirect effects are analyzed in the path analysis, it is understood that the effect of the environment is 0.022 on the relationship between experiential marketing and corporate reputation as the intermediate variable. The effects of social media knowledge and social media motivation as intermediary variables on experiential marketing were found as 0.073 and 0.040 , respectively.

As a result, $\mathrm{H} 3$ is rejected while the study's $\mathrm{H} 1$ and $\mathrm{H} 2$ hypotheses are accepted. In other words, the experiential marketing approach is significantly related to corporate reputation. While environmental variable influences the relationship between experiential marketing and corporate reputation, the social media variable has no effect.

\section{Conclusion}

The paper finds that sensory, emotional, cognitive, behavioral, relational experience affect corporate reputation directly or indirctly through environment.

The importance of consumer behaviour and being active on social media via Youtube, Facebook, Twitter and others come to exist in the study. Companies reserve a share of advertising budgets, especially to reach the $y$ and $z$ generation and affect their purchase intentions. Consequently, in the study all variables are positively related to each other and shows satisfactory levels. These results suggest that marketers need to take into account and manage actively experiential marketing activities, their environments, social media sites.

\section{References}

[1] Dima, A. M., Vasilache, S., Ghinea, V., \& Agoston, S., (2013), A model of academic social responsibility. Transylvanian Review of Administrative Sciences, 9(38), 23-43

[2] Fombrun Charles - Mark Shanley (1990) "What's In A Name? Reputation Building And Corporate Strategy." The Academy Of Management Journal, Vol. 33, No. 2, Pp. 233-258.

[3] Torlak, Ö., R. Altunışık, Ş. Özdemir, 2007, Yeni Müşteri, Hayat Yayınları, İstanbul

[4] Deligöz Kadir, 2016, Deneyimsel Pazarlama, Siyasal Kitabevi, Ankara

[5] Zaltman Gerald, 2004, Tüketici Nasıl Düşünür, Çev. Semih Koç, Marka Yayınları, İstanbul 
[6] Freemantle, D., 2000, Müşteri Neden Hoşlanır, Çev. İsmail Hunut, BZD Yayıncılık, İstanbul

[7] Kalyoncuoğlu Selma, 2017, Deneyimsel Pazarlama, Gazi Kitabevi, Ankara

[8] Schmitt Bernd, (1999), "Experiential Marketing," Journal Of Marketing Management, 15(1-3), Pp. 53-67

[9] Yaman Zührem, Muammer Zerenler, 2018, Deneyimsel Pazarlama, Gazi Kitabevi, Ankara

[10] Fombrun Charles - Mark Shanley (1990) "What's In A Name? Reputation Building And Corporate Strategy." The Academy Of Management Journal, Vol. 33, No. 2, Pp. 233-258.

[11] Caruana Albert, (1997) "Corporate Reputation: Concept And Measurement", Journal Of Product \& Brand Management, Vol. 6 Iss: 2, Pp.109 - 118

[12] Morden Tony, (1997) "Leadership as vision", Management Decision, Vol. 35 Issue: 9,Pp.668-676

[13] Bareket Granit Almog, (2012) "Visionary leadership in business schools: an institutional framework", Journal of Management Development, Vol. 31 Issue: 4, Pp.431-440

[14] Inglis Robert, Clive Morley, Paul Sammut, (2006),"Corporate reputation and organisational performance: an Australian study", Managerial Auditing Journal, Vol. 21 Iss 9 Pp. 934 - 947

[15] Fombrun, C., Gardberg, N.A. and Sever, J.M. (2000), The reputation quotient: A multi-stakeholder measure of corporate reputation, Journal of Brand Management, 7 (4), pp. 241-255.

[16] Porter Michael E., 1990, "The Competitive Advantage of Nations" Harvard Business Review, Pp. 1-30

[17] Marsh, H.W., Hocevar, D. (1985). Application of confirmatory factor analysis to the study of self-concept: Firstand higher-order factor models and their invariance across groups. Psychological Bulletin, 97, 562-582.

[18] Bentler, P.M. (1990). Comparative fit indexes in structural models. Psychological Bulletin, 107, 238-246

[19] Browne, M.W., Cudeck, R. (1993). Alternative ways of assessing model fit. In Bollen, K.A. \& Long, J.S. [Eds.] Testing structural equation models. Newbury Park, CA: Sage, 136-162

[20] Tanaka, J.S. \& Huba, G.J. (1985). A fit index for covariance structure models under arbitrary GLS estimation. British Journal of Mathematical and Statistical Psychology, 38, 197-201. 